\title{
Disruption in iron homeostasis and impaired activity of iron-sulfur cluster containing proteins in the yeast model of Shwachman-Diamond syndrome
}

\author{
Ayushi Jain ${ }^{1}$, Phubed Nilatawong ${ }^{1,2}$, Narinrat Mamak $^{3}$, Laran T. Jensen ${ }^{4}$ \\ and Amornrat Naranuntarat Jensen ${ }^{1,5,6^{*}}$ (1)
}

\begin{abstract}
Background: Shwachman-Diamond syndrome (SDS) is a congenital disease that affects the bone marrow, skeletal system, and pancreas. The majority of patients with SDS have mutations in the SBDS gene, involved in ribosome biogenesis as well as other processes. A Saccharomyces cerevisiae model of SDS, lacking Sdo1p the yeast orthologue of SBDS, was utilized to better understand the molecular pathogenesis in the development of this disease.

Results: Deletion of SDO1 resulted in a three-fold over-accumulation of intracellular iron. Phenotypes associated with impaired iron-sulfur (ISC) assembly, up-regulation of the high affinity iron uptake pathway, and reduced activities of ISC containing enzymes aconitase and succinate dehydrogenase, were observed in sdo $1 \Delta$ yeast. In cells lacking Sdo 1 p, elevated levels of reactive oxygen species (ROS) and protein oxidation were reduced with iron chelation, using a cell impermeable iron chelator. In addition, the low activity of manganese superoxide dismutase (Sod2p) seen in sdo1 $\triangle$ cells was improved with iron chelation, consistent with the presence of reactive iron from the ISC assembly pathway. In yeast lacking Sdo $1 \mathrm{p}$, the mitochondrial voltage-dependent anion channel (VDAC) Por1 p is overexpressed and its deletion limits iron accumulation and increases activity of aconitase and succinate dehydrogenase.
\end{abstract}

Conclusions: We propose that oxidative stress from POR1 over-expression, resulting in impaired activity of ISC containing proteins and disruptions in iron homeostasis, may play a role in disease pathogenesis in SDS patients.

Keywords: Shwachman-diamond syndrome, Iron overload, Yeast, Iron sulfur cluster, POR1 overexpression

\section{Background}

Shwachman-Diamond syndrome (SDS) is an autosomal recessive disorder characterized as a ribosomopathy [1-4]. Defects in ribosome biogenesis, due to mutations in ribosomal proteins and assembly factors, can lead to a wide range of clinical phenotypes [5]. Patients with SDS suffer from bone marrow failure, exocrine pancreatic

*Correspondence: amornrat.nar@mahidol.ac.th

${ }^{1}$ Department of Pathobiology, Faculty of Science, Mahidol University, 272 Rama 6 Road, Bangkok 10400, Thailand

Full list of author information is available at the end of the article dysfunction, skeletal abnormalities, and have a high risk of malignant transformation [6-11]. Even though SDS is a rare genetic disorder, it is a common cause of inherited exocrine pancreatic dysfunction and bone marrow failure [12-15].

The majority of SDS patients have loss of function mutations in SBDS (SDS1, OMIM \#260400) [16]. The best characterized function of SBDS is its role in the release and recycling of eIF6 from pre-60S ribosomes, a process that also involves the GTPase activity of Elongation Factor-Like 1 (EFL1) (SDS2, OMIM \# 617941) [17-20]. The 
release of eIF6 is a required step in the maturation of the $60 \mathrm{~S}$ ribosomal subunit $[1,3,21,22]$. Reduced formation of mature $60 \mathrm{~S}$ ribosome subunits results in impaired protein translation in cells with SDS deficiency [3, 23, 24]. SBDS physically interacts with EFL1 and mutations in EFL1 are also associated with SDS [17-20]. Interestingly, several SBDS missense mutations reduce binding affinity with EFL1 [18]. In addition, clinical features similar to SDS have been reported for mutations in DnaJ Heat Shock Protein Family (Hsp40) Member C21 (DNAJC21, OMIM \# 617052), a protein that may act as a co-chaperone for HSP70 $[25,26]$ and the Signal Recognition Particle 54 (SRP54, OMIM \# 618752), that binds to the signal sequence of presecretory proteins when they emerge from the ribosomes and directs them to the translocon on the endoplasmic reticulum membrane $[27,28]$.

SBDS is a multi-functional protein and SBDS mutations impact processes beyond ribosome biogenesis. Additional proposed functions for SBDS include rRNA processing [22, 29, 30], cellular stress responses [31, 32], and lysosome function [33]. Cells depleted for SBDS also appear to be under a chronic state of stress [34-36] and are sensitized to agents that impair endoplasmic reticulum (ER) function and conditions that promote DNA damage [31]. Mammalian cells deficient for SBDS and yeast cells lacking Sdo1p, the orthologue of SBDS, also display sensitivity to oxidative and osmotic stress [32, 37]. Yeast deleted for $S D O 1$ exhibit mitochondrial dysfunction, instability of mtDNA, and decreased activity of mitochondrial manganese superoxide dismutase (Sod2p) $[32,38,39]$. Stress sensitivity and mitochondrial dysfunction in cells deficient for SBDS/Sdo1p appears to be separate from attenuated protein translation [31, 32, 39].

Even with better understanding of the functions of SBDS/Sdo1p, the molecular mechanisms of how mutations in SBDS impact disease progression remains unclear. Current treatments for SDS patients do not target the underlying cause of the disease and instead are aimed at alleviating symptoms of this disorder. Elucidation of the key steps in the cellular pathogenesis of SDS should enable the development of therapies capable of targeting deficiencies leading to the disease state.

Using a Saccharomyces cerevisiae model of SDS, we examined potential causes of cellular stress from impaired Sdo1p function. Oxidative damage and inactivation of Sod2p in $s d o 1 \Delta$ cells previously described [39] were similar to effects seen in yeast mutants that overaccumulate intracellular iron due to defects in iron sulfur cluster (ISC) biogenesis [40, 41]. Examination of cellular iron content demonstrated that $s d o 1 \Delta$ cells accumulate three-fold more iron compared to wild-type yeast. Limiting iron accumulation in $s d o 1 \Delta$ cells reduced oxidative damage and environmental stress sensitivity as well as rescuing low activity of Sod2p. However, impaired activity of ISC enzymes in sdo1 $\Delta$ cells was not restored with iron chelation. Deletion of POR1 is known to alleviate stress sensitivity in $s d o 1 \Delta$ cells [32] and we report that iron accumulation is also reduced in por $1 \Delta$ sdo $1 \Delta$ yeast. In addition, activity of ISC enzymes in $s d o 1 \Delta$ cells was improved by prior deletion of POR1. Our results indicate that loss of Sdo1p is linked to disruptions in ISC biogenesis, mediated by over-expression POR1, that potentially promotes subsequent iron over-accumulation.

\section{Results}

\section{Cells deficient for Sdo1p display elevated iron content}

Our previous studies reported elevated oxidative stress as well as reduced levels and activity of manganesecontaining superoxide dismutase 2 (Sod2p) in yeast cells lacking Sdo1p [32, 39]. Iron released from the ISC biogenesis pathway is highly reactive and can inactivate Sod2p through competition with manganese binding to this enzyme [40, 41]. We therefore investigated whether iron homeostasis is altered in $s d o 1 \Delta$ yeast. Cells lacking Sdo1p accumulated three-fold higher levels of iron compared to wild-type yeast (Fig. 1a), similar to that seen for several yeast mutants with defects in ISC biogenesis [4247]. The elevated iron content of $s d o 1 \Delta$ cells does not appear to be associated with loss of mitochondrial DNA (mtDNA), as iron content in a rho ${ }^{0}$ strain lacking mtDNA was similar to WT yeast (Fig. 1a).

Reduced translational efficiency observed in $s d o 1 \Delta$ cells $[1,2]$, was not associated with iron over-accumulation. Yeast mutants that exhibit reduced polysome numbers: $d b p 3 \Delta, d b p 7 \Delta, d o m 34 \Delta$ and yar1 $\Delta$ [48-51] did not exhibited increased iron content relative to WT cells (Fig. 1b). Similarly, limiting protein synthesis in WT cells using cycloheximide did not result in elevated iron accumulation (Fig. 1c). These results indicate that iron overaccumulation in cells lacking Sdo1p is not directly linked to the reduced translational efficiency.

\section{Depletion of iron improves the activity of manganese-superoxide dismutase Sod $2 p$ and reduces oxidative stress in cells lacking Sdo1p}

We speculated that iron over-accumulation may contribute to the lowered levels of Sod2p activity in sdo1s cells. Treatment with the cell impermeable iron chelator, bathophenanthroline disulfonic acid (BPS), significantly reduced iron content of $s d o 1 \Delta$ cells (Fig. 2a), without altering growth rates (Fig. 2b). As seen in Fig. 2c, $\mathrm{d}$, Sod2p activity was increased in iron depleted $s d o 1 \Delta$ cells, suggesting that the excess iron in $s d o 1 \Delta$ can bind and inactivate Sod2p. However, following iron depletion the abundance of Sod2p protein in $s d o 1 \Delta$ yeast remained low compared to WT cells (Fig. 2c and e). This indicates 


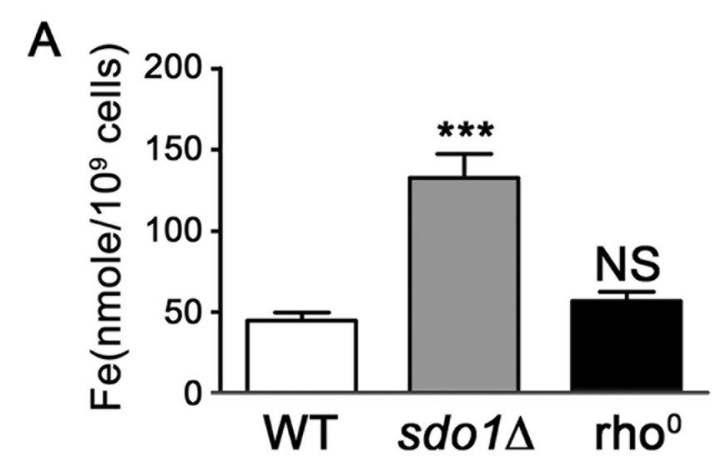

B

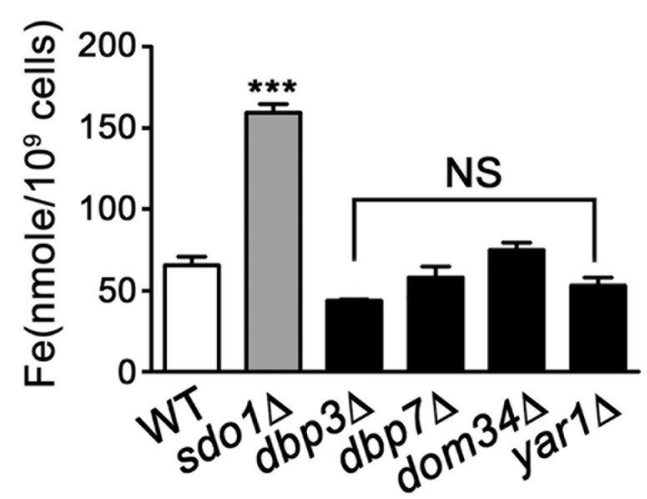

C

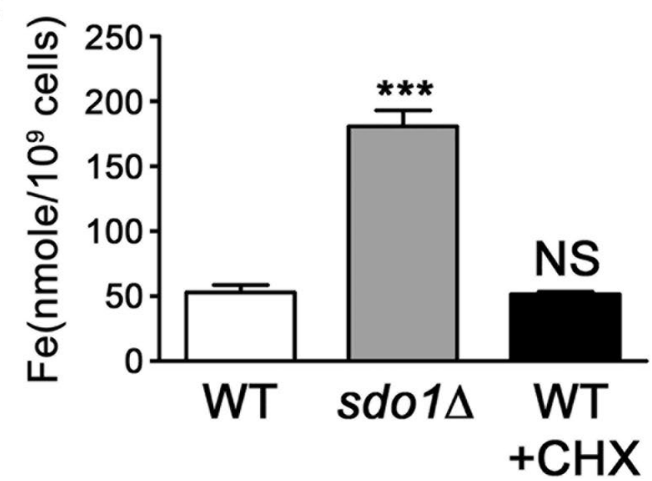

Fig. 1. Over-accumulation of intracellular iron was observed in cells deficient for Sdo1 p. a, b Wild type (WT), sdo $1 \Delta, r^{\circ} o^{\circ}$, and ribosome defective mutants ( $d b p 3 \Delta, d b p 7 \Delta$ dom $34 \Delta$ and yar $1 \Delta$ ) were cultured overnight in liquid YPD medium and the intracellular iron content was measured using graphite furnace atomic absorption spectrometry. Data shown are from three independent experiments. c Yeast were treated with $0.1 \mathrm{mg} / \mathrm{mL}$ cycloheximide (CHX) for 15 minutes to inhibit translation, intracellular iron levels were measured as described above. Data shown are from three independent experiments. Values are mean $+S D$, ${ }^{* * *} P<0.001$, NS: not significant, determined using Student's T-test compared to WT.

that the proposed iron incorporation into Sod2p only accounts for a portion of the loss of Sod2p activity in sdo1 $\Delta$ cells.

Consistent with this observation, ROS levels in cells lacking Sdo1p were also significantly reduced when iron content was limited by growth with BPS; however, ROS production remained elevated compared to cells with intact Sdo1p (Fig. 3a). Protein oxidation from $\mathrm{H}_{2} \mathrm{O}_{2}$ exposure was also significantly decreased in cells lacking Sdo1p when intracellular iron was depleted (Fig. 3b and c). Limiting iron with BPS was capable of enhancing growth of $s d o 1 \Delta$ cells exposed to $\mathrm{H}_{2} \mathrm{O}_{2}(3.5 \mathrm{mM})$ and to a lesser extent $8 \%$ ethanol (Fig. 3d). However, iron depletion did not alleviate slow growth of $s d o 1 \Delta$ yeast under conditions of heat stress $\left(37^{\circ} \mathrm{C}\right)$, reductive stress $(10 \mathrm{mM}$ $\beta$-ME), or salt stress $(600 \mathrm{mM} \mathrm{NaCl})$. It appears that the excess iron present in cells deficient for Sdo1p contributes to the elevated oxidative stress and damage seen in this strain with lowered Sod2p activity likely aggravating this effect.

Mis-regulation of iron uptake and impaired activities of ISC enzymes in cells deficient for Sdo1p

Defects in ISC formation lead to mis-regulation of iron uptake and iron over-accumulation [42, 43, 52, 53]. The yeast FET3 gene, encoding a homologue of ceruloplasmin, is required for high affinity iron uptake and its expression is elevated under conditions of ISC deficiency $[54,55]$. FET3 expression, monitored using a FET3lac $Z$ reporter plasmid, was approximately four times higher in $s d o 1 \Delta$ cells compared to WT (Fig. 4a), indicating impaired sensing of iron status. The activities of the ISC-containing enzymes aconitase and succinate dehydrogenase are also significantly reduced in the $S D O 1$ deletion strain, a rho ${ }^{0}$ strain lacking mtDNA was used as a control (Fig. 4b, c). In contrast to the partial rescue of Sod2p activity by iron depletion, treatment with BPS did not enhance activity of aconitase or succinate dehydrogenase (Fig. 4d, e). It appears that cells lacking Sdolp have defects in ISC containing proteins and this is a likely cause of mis-regulation of iron sensing leading to the increased labile pool of intracellular iron.

\section{Deletion of POR 1 in sdo1 $1 \Delta$ cells limits iron} over-accumulation and enhances activity of ISC enzymes Protein levels of Por1p, the yeast orthologue of human mitochondrial outer membrane VDAC, are significantly increased in $s d o 1 \Delta$ yeast $[32,38]$. We previously demonstrated that prior disruption of POR1 is able to substantially abrogate the effects of SDO1 deletion [32], including improving Sod2p activity [39]. Prior deletion of $P O R 1$ is able to significantly reduce iron content of $s d o 1 \triangle$ cells (Fig. 5a) and prevents induced expression of FET3 (Fig. 5b). In addition, increased activity of aconitase and succinate dehydrogenase is observed in por $1 \Delta s d o 1 \Delta$ cells relative to the $s d o 1 \Delta$ strain, although the activity of these enzymes remains low compared to WT yeast (Fig. 5c, d). These data suggest that increased expression of Por1p 
A

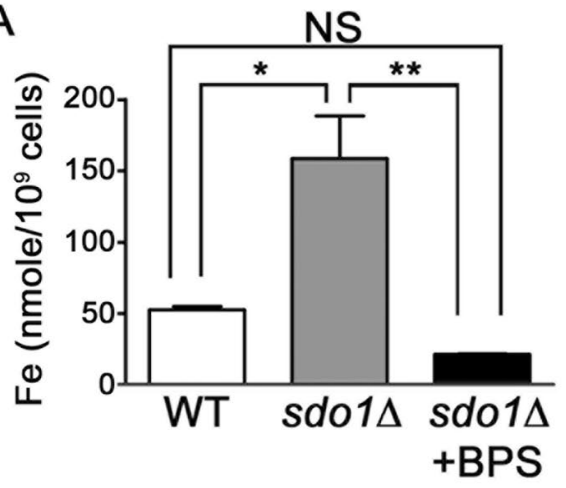

C

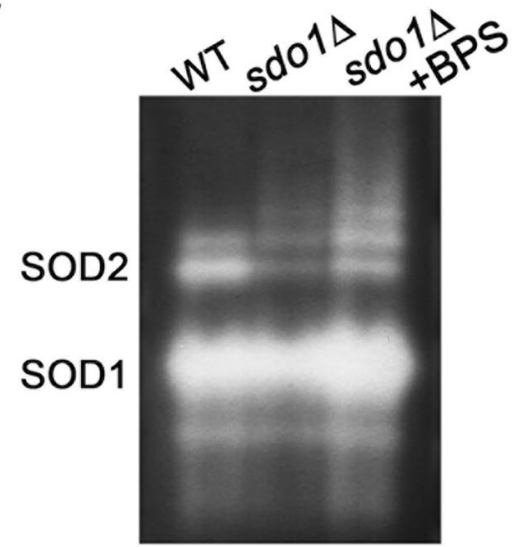

anti-

Sod2p

anti-
Pgk1p
B
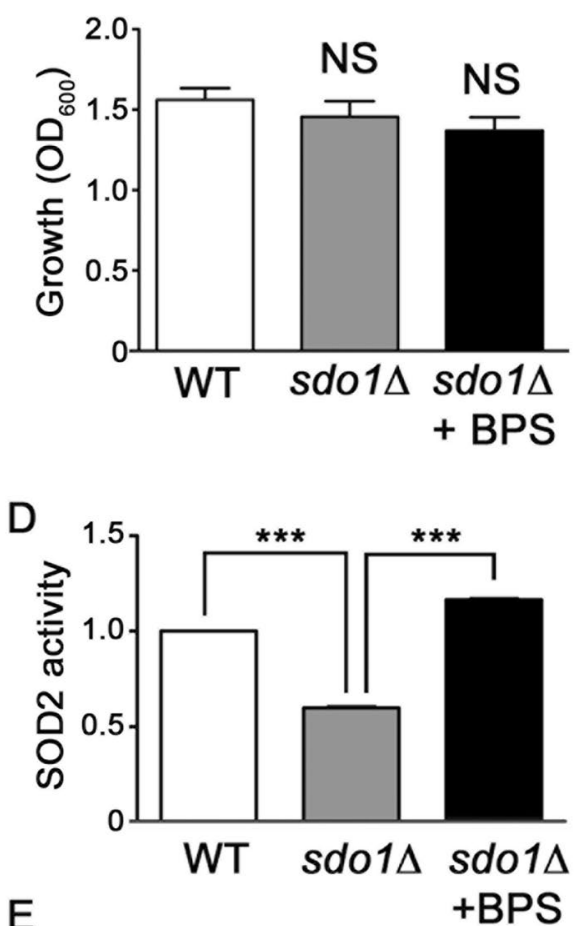

E

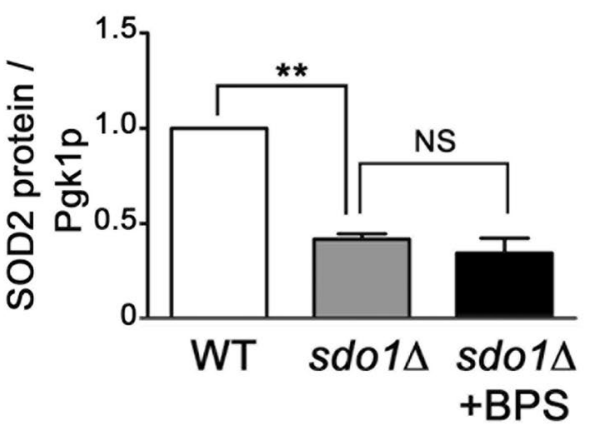

Fig. 2. Iron depletion enhances Sod $2 p$ activity in sdo $1 \triangle$ cells. The designated strains were cultured in YPD medium containing where indicated (+BPS) 40 MM BPS. a The intracellular iron levels were examined as in Fig. 1. Data shown are from three independent experiments. b Growth was monitored by monitoring OD $600 \mathrm{~nm}$ at 21 hours. c Whole-cell lysates were analyzed for SOD activity by native gel electrophoresis and nitroblue tetrazolium staining. SOD 1 and SOD2 indicate positions of active Cu/Zn-containing Sod $1 \mathrm{p}$ and manganese-containing Sod2p respectively. Sod $2 \mathrm{p}$ and Pgk1p polypeptides from the whole-cell lysates were analyzed by immunoblot (bottom panel). $\mathbf{d}$ Sod2p activity was quantitated and expressed as ratio of Sod2p activity/Pgk1 p for each sample, normalized to WT = 1. e Quantitation of Sod2p protein levels normalized to Pgk1 p abundance in each sample, with WT $=1$. Results are from two independent experiments. Values are the mean $+\mathrm{SD}$. ${ }^{* * * P}<0.001,{ }^{* * P}<0.01$, ${ }^{*} \mathrm{P}<0.05$, and NS (not significant) determined using Student's T-test compared between the means of two indicated groups.

in $s d o 1 \Delta$ cells plays a role in loss of enzymatic activity of ISC-containing proteins, promoting mis-regulation of iron uptake and over-accumulation of intracellular iron.

\section{Discussion}

The majority of SDS patients have mutations in the $S B D S$ gene, which encodes a protein important for ribosomal maturation $[1,16]$. However, SBDS appears to be involved in other cellular pathways including chemotaxis
[56], response to stress [31, 36, 57], and cell survival [58, 59]. Even with better understanding of SBDS functions beyond ribosome biogenesis, the molecular mechanisms of how loss of SBDS impacts disease progression remains unclear.

The use of simple model organisms can aid in understanding how disease associated mutations lead to pathogenesis at a cellular level. The yeast model of SDS in which $S D O 1$, the yeast orthologue of human $S B D S$, has 


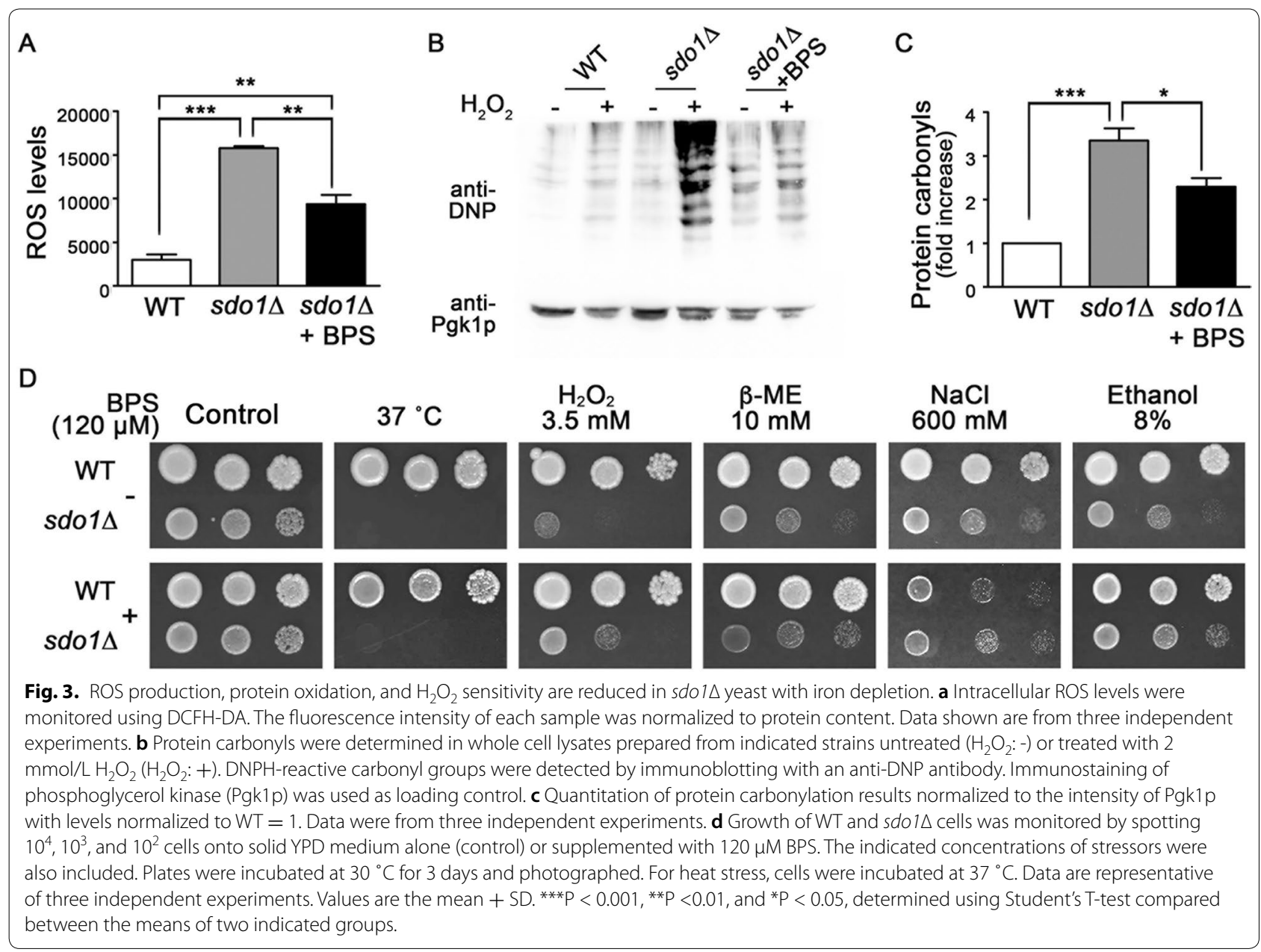

been deleted has facilitated the identification of additional pathways that require this gene for normal function. Enhanced sensitivity to oxidative stress insults and damage to mitochondria is apparent in yeast lacking Sdo1p [32, 39]. These effects appear to be mediated in part through a significant reduction in activity of Sod2p [39], a key enzyme required for defense against ROS produced in mitochondria [60].

Defects in mitochondrial processing and clearance of Sod2p presequence peptides has been suggested to contribute to reduced Sod2p activity and protein in $s d o 1 \Delta$ cells [39]. Additionally, several reports have linked reduced Sod2p activity to over-accumulation of iron, where excess iron competes with manganese for occupancy of the Sod2p active site. These observations are from both yeast disease models and tissues of patients suffering from diseases associated with iron overload, such as Friedrich's Ataxia and hemochromatosis [40, 41, $61,62]$.

Interestingly, expression of transferrin receptor 2 (TFR2), involved in iron homeostasis, is upregulated in
SBDS deficient cells [34]. Over-expression of TFR2 in cultured human cells leads to increased iron uptake and accumulation [63]. We speculated that elevated iron accumulation may impact SDS progression, potentially through enhancing oxidative stress and interfering with manganese incorporation into Sod2p. Consistent with the reported increase of TFR2 expression in SDS cells, sdo1 $\Delta$ yeast accumulate three times more intracellular iron compared to cells with intact Sdo1p. Although differences exist in the regulation and use of cellular iron between human and yeast cells, many aspects are similar. Genes involved in ISC assembly and non-heme iron uptake are largely conserved between yeast and human cells [64-66]. The regulation of iron uptake and storage genes is distinct with transcriptional systems present in yeast compared to translational or post-translational regulation in human cells $[67,68]$. However, sensing of iron status in both human and yeast utilizes ISCs as the signaling molecule $[69,70]$.

Our findings indicate that the elevated iron content of sdo1 $\Delta$ yeast is not associated with loss of mitochondrial 


\section{A}
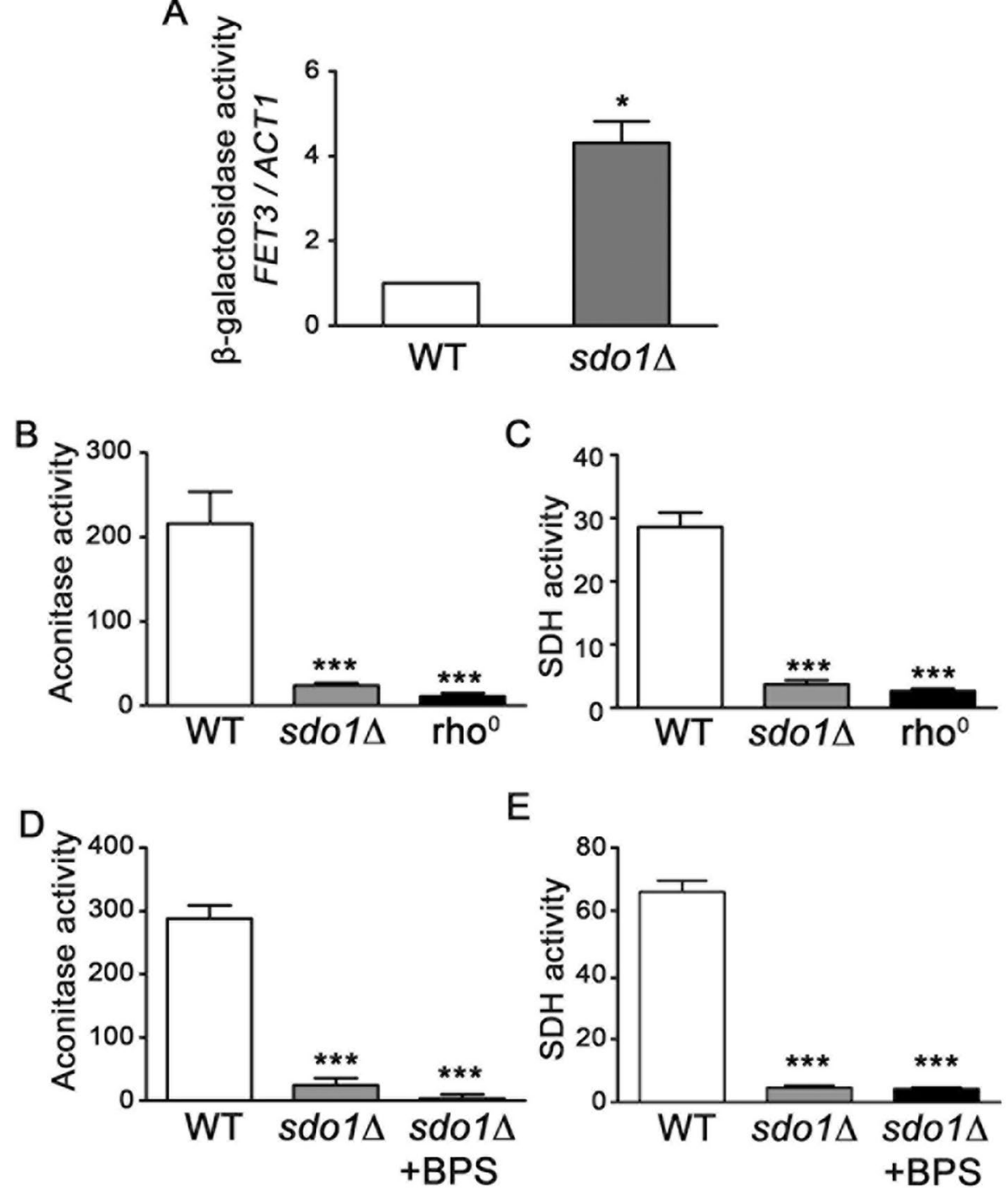

E

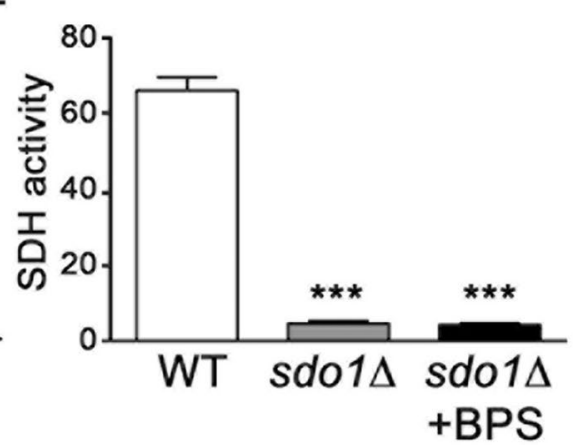

Fig. 4. Cells lacking Sdo1p show a reduction in ISC enzyme activities. a The induction of FET3 utilizing FET3-lacZ reporter plasmid containing the lacZ gene under control of the FET3 element was monitored. WT and sdo $1 \triangle$ cells were transformed with the plasmid pLJ440 (FET3-lacZ). Transformed cells were cultured in SC-URA selective media for 21 hours at $30^{\circ} \mathrm{C}$ until the $\mathrm{OD}_{600}$ of approximately 1.2. Data shown are from three independent experiments. b Aconitase activity was measured using whole cell lysates of WT, sdo $1 \triangle$ and rho $0^{\circ}$ cells. The cells were cultured in YPD media with $2 \%$ glucose as a carbon source for 40 hours in order to reach stationary phase following by extraction of proteins to determine the activity. Data shown are from three independent experiments. c Succinate dehydrogenase (SDH) activity was measured in WT, sdo $1 \Delta$ and rho ${ }^{\circ}$ cells. The cells were cultured in YPD media with $2 \%$ glucose as a carbon source for 40 hours in order to reach stationary phase following by mitochondrial isolation and protein extraction for determining the SHD activity. Data shown are from three independent experiments. $\mathbf{d}$ and $\mathbf{e}$ Activities of aconitase and SDH were monitored in WT, sdo $1 \triangle$ and sdo $1 \triangle$ strain treated with BPS. BPS was added to the media 24 hours before culture. Cells were cultured and the activities of aconitase and SDH were analyzed as described in $\mathbf{b}$ and $\mathbf{c}$ respectively. Data shown are from three independent experiments. Values are the mean $+\mathrm{SD}$. ${ }^{* *} \mathrm{P}<0.001$ and ${ }^{*} \mathrm{P}<0.05$, determined using Student's T-test compared to WT.

DNA, defects in ribosome biogenesis, or reduced protein translation. Yeast strains lacking mtDNA or carrying deletions for genes involved in ribosome maturation show similar iron content to wild-type cells. In addition, chemical inhibition of protein translation in wild type yeast cells does not promote iron accumulation. Limiting iron availability, through the use of a cell impermeable iron chelator (BPS) significantly decreased ROS levels in cells lacking Sdo1p. Oxidative damage to proteins following hydrogen peroxide stress was also reduced by iron chelation of $s d o 1 \Delta$ cells. It appears that iron mediated 
A

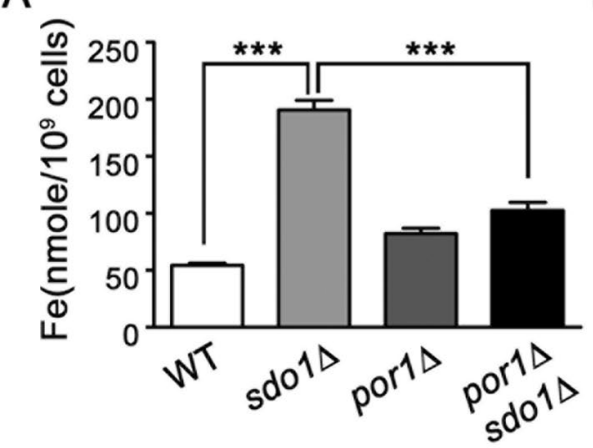

C

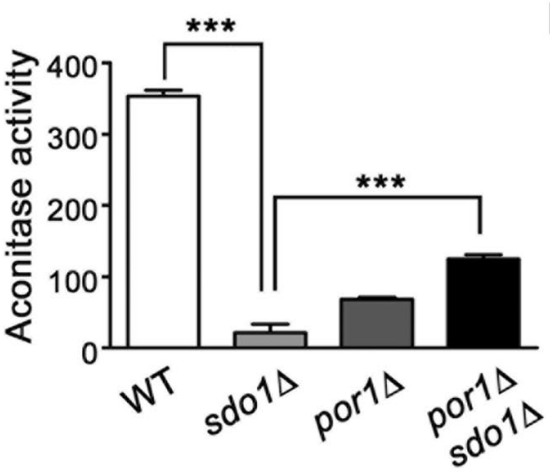

B

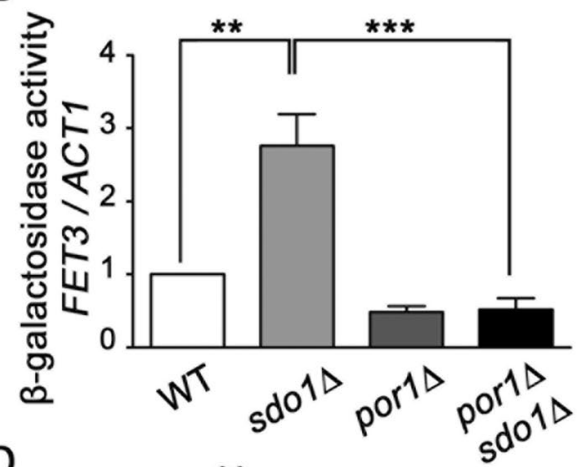

D

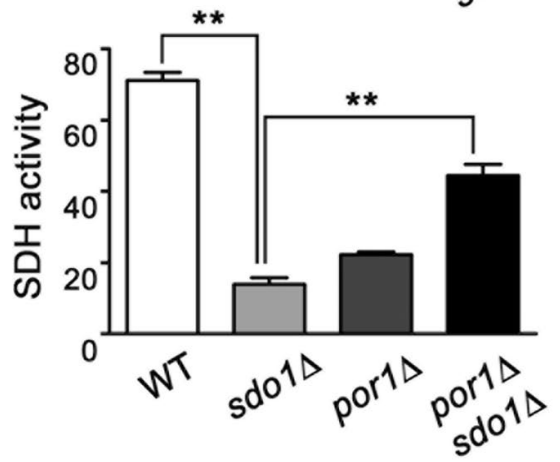

Fig. 5. Prior deletion of $P O R 1$ restores defects observed in cells lacking Sdo 1 p. a Intracellular iron levels of $W T$, sdo $1 \triangle$, por $1 \triangle$ and sdo $1 \triangle p$ or $1 \triangle$, as indicated, were examined as described in Fig. 1. Data were from three independent experiments. b-d The induction of FET3-lacZ and activities of aconitase and succinate dehydrogenase were monitored as described in Fig. 4. Indicated strains were cultured in YPD media with $2 \%$ glucose for 40 hours until reaching stationary phase. Data were from three independent experiments. Values are the mean $+\mathrm{SD}$. ${ }^{* *} \mathrm{P}<0.001$ and ${ }^{* * *}<0.01$ determined using Student's T-test compared between the means of two indicated groups

formation of ROS is a major cause of oxidative stress in cells lacking Sdo1p.

The active site of Sod2p can bind to both iron and manganese with similar affinities, although binding of iron results in an inactive form of the enzyme [71, 72]. Sod2p activity was enhanced following iron chelation, indicating that reduced activity of this enzyme is mediated in part through inappropriate binding of iron to its active site. Surprisingly, the level of Sod2p protein was not increased with iron chelation. Thus, it seems that the lowered Sod2p protein levels are not due to iron over-accumulation but instead appear to be linked to the impaired import of pre-Sod2p into mitochondria previously reported [39]. However, excess iron further limits the activity of Sod2p in addition to the effect seen from reduced accumulation of the Sod2p protein. Preventing accumulation of excess iron appears to be sufficient to reduce competition between iron and manganese for access to the Sod2p active site in $s d o 1 \Delta$ cells, enhancing Sod2p activity.

Distinct pools of iron are present in mitochondria and iron released from ISC proteins or from the ISC biogenesis pathway is highly reactive with Sod2p and can limit the activity of this enzyme [40, 41]. A wellestablished cellular response to defects in the ISC pathway is increased expression of genes involved in iron uptake [54], including FET3, encoding a homologue of ceruloplasmin [73]. In yeast lacking Sdo1p, FET3 expression was significantly increased relative to wildtype cells, consistent with a defect in the mitochondrial ISC pathway [54, 74, 75]. Significant reductions in the activity of ISC-containing enzymes aconitase and succinate dehydrogenase was also observed in $s d o 1 \Delta$ yeast. Iron chelation did not restore the activity of aconitase or succinate dehydrogenase in $s d o 1 \Delta$ cells, suggesting that inactivation of these enzymes may not be a direct result of iron-induced oxidative damage. Although it is possible that the loss of ISC enzyme activities in irondepleted cells is due to the fact that the cells remain lacking of mitochondrial DNA as we can observe loss of similarly loss of ISC enzyme activities in rho ${ }^{0}$ strain. Taken together these observations are consistent with impairment of the ISC pathway, which may be the source of iron over-accumulation due to deletion of SDO1. 
The connection between loss of Sdo1p and impaired activity of the ISC pathway remains unclear. However, a significant over-expression of POR1, encoding a mitochondrial voltage-dependent anion channel (VDAC), has been demonstrated in cells lacking Sdo1p [32, 38]. Over-expression of POR1 results in oxidative damage to proteins and increased sensitivity to hydrogen peroxide [32]. The impact of loss of Sdo1p on the ISC pathway may be mediated through its effects on Por1p over-accumulation and resulting oxidative stress. The ISC biosynthesis pathway as well as many mature ISC containing enzymes, such as aconitase, are sensitive to ROS [76, 77]. Release of iron from the ISC pathway can contribute to elevated iron content, leading to a further increase in ROS production [41, 46, 78]. In this analysis, prior deletion of POR1 in sdo1 $\triangle$ strains was found to significantly restore regulation of iron metabolism, lowering cellular iron content, and enhancing the activity of aconitase and succinate dehydrogenase. Prior deletion of POR1 was previously found to significantly increase Sod2p activity in $s d o 1 \Delta$ cells [39], consistent with the results reported here for iron chelation, further indicating a link between elevated Por1p levels and mis-regulation of iron homeostasis.

\section{Conclusions}

The findings from this study have revealed a novel pathway affected by impaired Sdolp activity. The mechanisms that promote iron over-accumulation and impaired ISC biogenesis in cells lacking Sdo1p remain to be clarified. However, elevated ROS observed in SBDS deficient cells [34] as well as $s d o 1 \Delta$ yeast [32] may contribute to cellular damage and dysfunction. ISCs in many proteins are ROS labile and their disassembly can contribute to increased levels of reactive cellular iron $[41,79]$. A cycle in which ROS mediated release of iron from ISCs promotes ROS formation may be contributing to cellular damage seen in $s d o 1 \Delta$ cells. Impaired activity of Fe-S containing enzymes in the mitochondrial respiratory chain was observed in cells lacking Sdo1p. We propose that these effects are a consequence of elevated ROS production, mediated by POR1 over-expression. Better understanding of how decreased Sdo1p/SBDS activity contributes to altered activity ISC enzymes and how these effects are associated with SDS pathogenesis, may aid in developing therapeutic strategies for this disease. If iron overaccumulation and impaired activity of ISC enzymes is confirmed in SDS patients, interventions that can alleviate these effects may aid in the management of SDS symptoms.

\section{Materials and methods}

\section{Yeast strains, culture conditions, and plasmids}

The strains utilized in this study are isogenic to haploid strains BY4741 (MATa, leu2 $\Delta 0$, met $15 \Delta 0$, ura $3 \Delta 0$, his $3 \Delta 1$ ) or BY4742 (Mata, leu2 $\Delta 0$, lys $2 \Delta 0$, ura $3 \Delta 0$, his3 $\Delta 1$ ). Strains AJ001 (BY4741, sdo1 $\Delta:: H I S 3)$, WK001 (BY4741, por1 $1:: K a n M X 4, \quad s d o 1 \Delta:: H I S 3)$, and LJ109 (BY4741 rho ${ }^{0}$ ) have been described previously [32, 53]. Deletion strains for DBP3, DBP7, DOM34, and YAR1 were obtained from Open Biosystems (Layafette, CO, USA). Cells were cultured at $30{ }^{\circ} \mathrm{C}$ on enriched yeast extract, peptone based medium supplemented with $2 \%$ glucose (YPD) [80]. For iron depleted conditions medium was adjusted to $\mathrm{pH} 6.0$ with 3-morpholinopropanesulfonic acid (MOPS) and $40 \mu \mathrm{M}$ or $120 \mu \mathrm{M}$ BPS was added to YPD broth or solid medium, respectively. Yeast transformations were performed using the lithium acetate procedure [81] and transformants were selected using synthetic complete (SC) medium lacking uracil. Promoter-lacZ reporter plasmids pLJ519 (ACT1-lacZ) and pLJ440 (FET3-lacZ) have been previously described $[82,83]$.

\section{Measurement of intracellular iron and ROS levels}

Cells were cultured overnight and were collected at OD600 of approximately 1 . Cell pellets were washed with Tris $\mathrm{HCl}$ with EDTA, pH 6.5 and then Type I water. Intracellular iron was measured using graphite furnace atomic absorption spectroscopy (PerkinElmer, USA). The iron concentration was reported as nmole $\mathrm{Fe} / 10^{9}$ cells. To measure intracellular ROS levels, cells at final OD600 of approximately 1 were incubated with $10 \mu \mathrm{M}$ 2,7-dichorofluorescein diacetate $\left(\mathrm{H}_{2} \mathrm{DCFDA}\right)$ (Sigma, U.S.A.) for one hour. Cells were lysed and the fluorescence signal was measured as described previously [84]. Fluorescence intensity was normalized to the protein concentration of each sample.

\section{Protein carbonylation analysis and immunoblots}

Carbonylated proteins were detected following derivatization with 2,4-dinitrophenylhydrazine (DNPH) [85]. Lysates were prepared using the glass bead homogenization in $10 \mathrm{mM} \mathrm{NaPO}_{4} \mathrm{pH} \mathrm{7.8,1 \%}$ Triton X-100, $5 \mathrm{mM}$ EDTA pH 8, and $50 \mathrm{mM} \mathrm{NaCl}$ from cells cultured in YPD medium alone or treated with $2 \mathrm{mmol} / \mathrm{L} \mathrm{H}_{2} \mathrm{O}_{2}$ for 1 hour. Whole cell lysates from each sample were reacted with DNPH for 15 minutes at room temperature and were resolved on denaturing polyacrylamide gels. DNP-derivatized proteins were detected with an anti-DNP antibody (Merck Millipore, USA) at a 1:5000 dilution. Sod2p protein was detected using anti-Sod2p antibody (JH633) provided by Dr. Valeria Culotta (Johns Hopkins University, USA) at a dilution of 1:5000 [86]. Pgk1p abundance 
was used in each experiment as loading control with an anti-Pgk1p antibody (Abcam, USA) at a 1:5000 dilution. Anti-mouse and anti-rabbit HRP conjugated secondary antibodies were utilized at a 1:10,000 dilution for ECL detection (Merck Millipore, USA). A G:Box Chemi XL1.4 chemiluminescence imaging system (Syngene, UK) was used for imaging of immunoblots. Quantitation was performed using ImageJ 1.45S software [87].

\section{Biochemical assays}

$\beta$-galactosidase assays utilized transformants containing either the FET3-lacZ or ACT1-lacZ reporters grown in synthetic media lacking uracil. Cell lysates were prepared using the glass bead homogenization procedure [88] and activity was assayed with, o-nitrophenyl-betaD-galactopyranoside (ONPG), in $60 \mathrm{mM} \mathrm{Na}_{2} \mathrm{HPO}_{4}, 40$ $\mathrm{mM} \mathrm{NaH}_{2} \mathrm{PO}_{4}, 10 \mathrm{mM} \mathrm{KCl}, 1 \mathrm{mM} \mathrm{MgSO}, 1 \mathrm{mM}$ phenylmethylsulfonyl fluoride, and $1 \mathrm{mM}$ dithiothreitiol. The results were assayed at least in duplicate and were reported in Miller units [89].

Superoxide dismutase activity assays were performed using yeast cells grown in YPD to a final OD600 of approximately 1 . Cell extracts were prepared and protein content of whole cell lysates was measured by Bradford assay [90]. SOD activity was analyzed by non-denaturing gel electrophoresis and staining with nitro blue tetrazolium (NBT) as previously described $[39,91]$

Aconitase and succinate dehydrogensase activity assays were performed according to published methods [52, 92, 93]. Briefly, cells were grown in YPD medium for 40 hours, reaching stationary phase. For analysis of aconitase activity, cells were lysed using glass bead homogenization in $\mathrm{KH}_{2} \mathrm{PO}_{4}(\mathrm{pH}$ 7.4) with $1 \mathrm{mM}$ phenylmethylsulfonyl fluoride. The activity of aconitase was monitored in $20 \mathrm{mM}$ Tris- $\mathrm{HCl} \mathrm{pH} \mathrm{7.4,} 100 \mathrm{mM} \mathrm{NaCl}$, and $0.5 \mathrm{mM}$ cis-aconitate following the conversion of cis-aconitate to isocitrate at $240 \mathrm{~nm}$ using a UV-Vis Spectrophotometer (UV-2600) (Shimadzu, Japan). Crude mitochondria for analysis of SDH activity were isolated from cell lysates prepared with glass homogenization in $0.6 \mathrm{M}$ sorbitol, $10 \mathrm{mM}$ HEPES (pH 7.4) containing 1 mM PMSF using differential centrifugation as previously described [94]. SDH activity was monitored in $50 \mathrm{mM}$ HEPES (pH 7.4), $0.1 \mathrm{mM}$ EDTA, $1 \mathrm{mM} \mathrm{KCN}, 100 \mu \mathrm{M}$ phenazine methosulfate, and $20 \mathrm{mM}$ succinate following the reduction of dichlorophenol indophenol $(5 \mu \mathrm{M})$ at $600 \mathrm{~nm}$ using a Genesys 20 Spectrophotometer (Thermo Spectronic, USA).

\section{Statistical analysis}

All data are presented as mean + standard deviation. One-way ANOVA with post-hoc Tukey test or T-test was used to determine statistical significance * $\mathrm{P}<0.05$, ${ }^{* * *} \mathrm{P}<$ 0.01 , and ${ }^{* * *} \mathrm{P}<0.001$.

\section{Abbreviations}

SDS: Shwachman-Diamond syndrome; ISC: Iron-sulfur cluster; VDAC: Voltagedependent anion channel; ER: Endoplasmic reticulum; BPS: Bathophenanthroline disulfonic acid; ROS: Reactive oxygen species.

\section{Acknowledgements}

We thank Valeria Culotta for the anti-Sod2p antibody and Pradup Meesawat for assistance with atomic absorption spectroscopy.

\section{Authors' contributions}

AJ performed experiments and wrote the original draft of the manuscript: PN performed experiments; NM performed experiments; LTJ: performed experiments and analyzed data, reviewed and edited the manuscript; ANJ initiated and supervised the project, performed experiments and analyzed data, reviewed and edited the manuscript. All authors read and approved final manuscript.

\section{Funding}

This research project was supported by Mahidol University under the New Discovery and Frontier Research Grant (NDFR 05/2563); the Faculty of Science, Mahidol University; the Central Instrument Facility, Faculty of Science, Mahidol University; and the Thailand Research Fund (RSA6180082).

\section{Availability of data and materials}

The datasets used and/or analyzed in the current study are available from the corresponding author upon request.

\section{Ethics approval and consent to participate}

Not applicable

\section{Consent for publication}

Not applicable

\section{Competing interests}

The authors declare no conflict of interest.

\section{Author details}

${ }^{1}$ Department of Pathobiology, Faculty of Science, Mahidol University, 272 Rama 6 Road, Bangkok 10400, Thailand. ${ }^{2}$ Division of Biopharmacy, Faculty of Pharmaceutical Sciences, Ubon Ratchathani University, Ubon Ratchathani 34190, Thailand. ${ }^{3}$ Toxicology Graduate Program, Faculty of Science, Mahidol University, Bangkok 10400, Thailand. ${ }^{4}$ Department of Biochemistry, Faculty of Science, Mahidol University, Bangkok 10400, Thailand. ${ }^{5}$ Pathology Information and Learning Center, Department of Pathobiology, Faculty of Science, Mahidol University, Bangkok 10400, Thailand. ${ }^{6}$ Center of Excellence on Environmental Health and Toxicology (EHT), Bangkok, Thailand.

Received: 22 June 2020 Accepted: 4 September 2020

Published online: 11 September 2020

\section{References}

1. Menne TF, Goyenechea B, Sanchez-Puig N, Wong CC, Tonkin LM, Ancliff PJ, et al. The Shwachman-Bodian-Diamond syndrome protein mediates translational activation of ribosomes in yeast. Nat Genet. 2007:39(4):486-95.

2. Moore JB, Farrar JE, Arceci RJ, Liu JM, Ellis SR. Distinct ribosome maturation defects in yeast models of Diamond-Blackfan anemia and Shwachman-Diamond syndrome. Haematologica. 2010;95(1):57-64.

3. Wong CC, Traynor D, Basse N, Kay RR, Warren AJ. Defective ribosome assembly in Shwachman-Diamond syndrome. Blood. 2011;118(16):4305-12.

4. Bezzerri V, Cipolli M. Shwachman-Diamond syndrome: molecular mechanisms and current perspectives. Mol Diagn Ther. 2018;23(2):281-90. 
5. Armistead J, Triggs-Raine B. Diverse diseases from a ubiquitous process: the ribosomopathy paradox. FEBS Lett. 2014;588(9):1491-500.

6. Bodian M, Sheldon W, Lightwood R. Congenital hypoplasia of the exocrine pancreas. Acta Paediatr. 1964;53:282-93.

7. Shwachman H, Diamond LK, Oski FA, Khaw KT. The syndrome of pancreatic insufficiency and bone marrow dysfunction. J Pediatr. 1964;65:645-63.

8. Mack DR, Forstner GG, Wilschanski M, Freedman MH, Durie PR. Shwachman syndrome: exocrine pancreatic dysfunction and variable phenotypic expression. Gastroenterology. 1996;111(6):1593-602.

9. Smith OP, Hann IM, Chessells JM, Reeves BR, Milla P. Haematological abnormalities in Shwachman-Diamond syndrome. Br J Haematol. 1996;94(2):279-84.

10. Ginzberg H, Shin J, Ellis L, Morrison J, Ip W, Dror Y, et al. Shwachman syndrome: phenotypic manifestations of sibling sets and isolated cases in a large patient cohort are similar. J Pediatr. 1999;135(1):81-8.

11. Makitie $\mathrm{O}$, Ellis L, Durie PR, Morrison JA, Sochett EB, Rommens JM, et al. Skeletal phenotype in patients with Shwachman-Diamond syndrome and mutations in SBDS. Clin Genet. 2004;65(2):101-12.

12. Ginzberg H, Shin J, Ellis L, Goobie S, Morrison J, Corey M, et al. Segregation analysis in Shwachman-Diamond syndrome: evidence for recessive inheritance. Am J Hum Genet. 2000;66(4):1413-6.

13. Federman N, Sakamoto KM. The genetic basis of bone marrow failure syndromes in children. Mol Genet Metab. 2005;86(1-2):100-9.

14. Lee JH, Bae SH, Yu JJ, Lee R, Yun YM, Song EY. A case of ShwachmanDiamond syndrome confirmed with genetic analysis in a Korean child. J Korean Med Sci. 2008:23(1):142-5.

15. Hall GW, Dale P, Dodge JA. Shwachman-Diamond syndrome: UK perspective. Archives of Disease in Childhood. 2006;91(6):521-4.

16. Boocock GR, Morrison JA, Popovic M, Richards N, Ellis L, Durie PR, et al. Mutations in SBDS are associated with Shwachman-Diamond syndrome. Nat Genet. 2003;33(1):97-101.

17. Stepensky P, Chacon-Flores M, Kim KH, Abuzaitoun O, Bautista-Santos A Simanovsky N, et al. Mutations in EFL1, an SBDS partner, are associated with infantile pancytopenia, exocrine pancreatic insufficiency and skeletal anomalies in aShwachman-Diamond like syndrome. J Med Genet. 2017;54(8):558-66.

18. Gijsbers A, Montagut D, Méndez-Godoy A, Altamura D, Saviano M, Siliqi $D$, et al. Interaction of the GTPase Elongation Factor Like-1 with the Shwachman-Diamond syndrome protein and its missense mutations. Int J Mol Sci. 2018;19:12.

19. Tan S, Kermasson L, Hoslin A, Jaako P, Faille A, Acevedo-Arozena A, et al. EFL1 mutations impair elF6 release to cause Shwachman-Diamond syndrome. Blood. 2019;134(3):277-90.

20. Tan QK, Cope H, Spillmann RC, Stong N, Jiang YH, McDonald MT, et al. Further evidence for the involvement of EFL1 in a Shwachman-Diamondlike syndrome and expansion of the phenotypic features. Cold Spring Harb Mol Case Stud. 2018:4:5.

21. Finch AJ, Hilcenko C, Basse N, Drynan LF, Goyenechea B, Menne TF, et al. Uncoupling of GTP hydrolysis from elF6 release on the ribosome causes Shwachman-Diamond syndrome. Genes Dev. 2011;25(9):917-29.

22. Luz JS, Georg RC, Gomes CH, Machado-Santelli GM, Oliveira CC. Sdo1p, the yeast orthologue of Shwachman-Bodian-Diamond syndrome protein binds RNA and interacts with nuclear rRNA-processing factors. Yeast. 2009;26(5):287-98.

23. Burwick N, Coats SA, Nakamura T, Shimamura A. Impaired ribosomal subunit association in Shwachman-Diamond syndrome. Blood. 2012;120(26):5143-52.

24. Calamita P, Miluzio A, Russo A, Pesce E, Ricciardi S, Khanim F, et al. SBDSDeficient Cells Have an altered homeostatic equilibrium due to translational inefficiency which explains their reduced fitness and provides a logical framework for intervention. PLoS Genet. 2017;13(1):e1006552.

25. Dhanraj S, Matveev A, Li H, Lauhasurayotin S, Jardine L, Cada M, et al. Biallelic mutations in DNAJC21 cause Shwachman-Diamond syndrome. Blood. 2017;129(11):1557-62.

26. Tummala H, Walne AJ, Williams M, Bockett N, Collopy L, Cardoso S, et al. DNAJC21 Mutations Link a Cancer-Prone Bone Marrow Failure Syndrome to Corruption in 60S Ribosome Subunit Maturation. Am J Hum Genet. 2016;99(1):115-24.

27. Carapito R, Konantz M, Paillard C, Miao Z, Pichot A, Leduc MS, et al. Mutations in signal recognition particle SRP54 cause syndromic neutropenia with Shwachman-Diamond-like features. J Clin Invest. 2017;127(11):4090-103.

28. Bellanne-Chantelot C, Schmaltz-Panneau B, Marty C, Fenneteau O, Callebaut I, Clauin S, et al. Mutations in the SRP54 gene cause severe congenital neutropenia as well as Shwachman-Diamond-like syndrome. Blood. 2018;132(12):1318-31.

29. Savchenko A, Krogan N, Cort JR, Evdokimova E, Lew JM, Yee AA, et al. The Shwachman-Bodian-Diamond syndrome protein family is involved in RNA metabolism. J Biol Chem. 2005;280(19):19213-20.

30. Wu LF, Hughes TR, Davierwala AP, Robinson MD, Stoughton R, Altschuler SJ. Large-scale prediction of Saccharomyces cerevisiae gene function using overlapping transcriptional clusters. Nat Genet. 2002:31(3):255-65.

31. Ball HL, Zhang B, Riches JJ, Gandhi R, Li J, Rommens JM, et al. Shwachman-Bodian Diamond syndrome is a multi-functional protein implicated in cellular stress responses. Hum Mol Genet. 2009;18(19):3684-95.

32. Kanprasoet W, Jensen LT, Sriprach S, Thitiananpakorn K, Rattanapornsompong K, Jensen AN. Deletion of mitochondrial porin alleviates stress sensitivity in the yeast model of Shwachman-Diamond Syndrome. J Genet Genomics. 2015;42(12):671-84.

33. Vitiello SP, Benedict JW, Padilla-Lopez S, Pearce DA. Interaction between Sdo $1 p$ and Btn $1 p$ in the Saccharomyces cerevisiae model for Batten disease. Hum Mol Genet. 2010;19(5):931-42.

34. Sen S, Wang H, Nghiem CL, Zhou K, Yau J, Tailor CS, et al. The ribosomerelated protein, SBDS, is critical for normal erythropoiesis. Blood. 2011;118(24):6407-17.

35. Ravera S, Dufour C, Cesaro S, Bottega R, Faleschini M, Cuccarolo P, et al. Evaluation of energy metabolism and calcium homeostasis in cells affected by Shwachman-Diamond syndrome. Sci Rep. 2016;6:25441.

36. Dror Y. P53 protein overexpression in Shwachman-Diamond syndrome. Arch Pathol Lab Med. 2002;126(10):1157-8.

37. Ambekar C, Das B, Yeger H, Dror Y. SBDS-deficiency results in deregulation of reactive oxygen species leading to increased cell death and decreased cell growth. Pediatr Blood Cancer. 2010;55(6):1138-44.

38. Henson AL, Moore JB, Alard P, Wattenberg MM, Liu JM, Ellis SR. Mitochondrial function is impaired in yeast and human cellular models of Shwachman Diamond syndrome. Biochem Biophys Res Commun. 2013;437(1):29-34.

39. Jensen LT, Phyu T, Jain A, Kaewwanna C, Jensen AN. Decreased accumulation of superoxide dismutase 2 within mitochondria in the yeast model of Shwachman-Diamond syndrome. J Cell Biochem. 2019;120(8):13867-80.

40. Yang M, Cobine PA, Molik S, Naranuntarat A, Lill R, Winge DR, et al. The effects of mitochondrial iron homeostasis on cofactor specificity of superoxide dismutase 2. EMBO J. 2006;25(8):1775-83.

41. Naranuntarat A, Jensen LT, Pazicni S, Penner-Hahn JE, Culotta VC. The interaction of mitochondrial iron with manganese superoxide dismutase. J Biol Chem. 2009;284(34):22633-40.

42. Babcock M, de Silva D, Oaks R, Davis-Kaplan S, Jiralerspong S, Montermini $L$, et al. Regulation of mitochondrial iron accumulation by Yfh $1 \mathrm{p}$, a putative homolog of frataxin. Science. 1997;276(5319):1709-12.

43. Garland SA, Hoff K, Vickery LE, Culotta VC. Saccharomyces cerevisiae ISU1 and ISU2: members of a well-conserved gene family for iron-sulfur cluster assembly. J Mol Biol. 1999;294(4):897-907.

44. Rodriguez-Manzaneque MT, Tamarit J, Belli G, Ros J, Herrero E. Grx5 is a mitochondrial glutaredoxin required for the activity of iron/sulfur enzymes. Mol Biol Cell. 2002;13(4):1109-21.

45. Gerber J, Neumann K, Prohl C, Muhlenhoff U, Lill R. The yeast scaffold proteins Isu $1 \mathrm{p}$ and Isu2p are required inside mitochondria for maturation of cytosolic Fe/S proteins. Mol Cell Biol. 2004;24(11):4848-57.

46. Jensen LT, Sanchez RJ, Srinivasan C, Valentine JS, Culotta VC. Mutations in Saccharomyces cerevisiae iron-sulfur cluster assembly genes and oxidative stress relevant to $\mathrm{Cu}$. Zn superoxide dismutase. J Biol Chem. 2004;279(29):29938-43.

47. Lesuisse E, Knight SA, Courel M, Santos R, Camadro JM, Dancis A. Genome-wide screen for genes with effects on distinct iron uptake activities in Saccharomyces cerevisiae. Genetics. 2005;169(1):107-22.

48. Weaver PL, Sun C, Chang TH. Dbp3p, a putative RNA helicase in Saccharomyces cerevisiae, is required for efficient pre-rRNA processing predominantly at site A3. Mol Cell Biol. 1997;17(3):1354-65. 
49. Daugeron MC, Linder P. Dbp7p, a putative ATP-dependent RNA helicase from Saccharomyces cerevisiae, is required for 605 ribosomal subunit assembly. RNA. 1998;4(5):566-81.

50. Bhattacharya A, McIntosh KB, Willis IM, Warner JR. Why Dom34 stimulates growth of cells with defects of 405 ribosomal subunit biosynthesis. Mol Cell Biol. 2010;30(23):5562-71.

51. Loar JW, Seiser RM, Sundberg AE, Sagerson HJ, Ilias N, Zobel-Thropp P, et al. Genetic and biochemical interactions among Yar1, Ltv1 and Rps3 define novel links between environmental stress and ribosome biogenesis in Saccharomyces cerevisiae. Genetics. 2004;168(4):1877-89.

52. Strain J, Lorenz CR, Bode J, Garland S, Smolen GA, Ta DT, et al. Suppressors of Superoxide Dismutase (SOD1) Deficiency in Saccharomyces cerevisiae: identification of proteins predicted to mediate iron-sulfur cluster assembly. J Biol Chem. 1998;273(47):31138-44.

53. Jensen LT, Culotta VC. Role of Saccharomyces cerevisiae ISA1 and ISA2 in iron homeostasis. Mol Cell Biol. 2000;20(11):3918-27.

54. Chen OS, Crisp RJ, Valachovic M, Bard M, Winge DR, Kaplan J. Transcription of the yeast iron regulon does not respond directly to iron but rather to iron-sulfur cluster biosynthesis. J Biol Chem. 2004;279(28):29513-8.

55. Rutherford JC, Ojeda L, Balk J, Muhlenhoff U, Lill R, Winge DR. Activation of the iron regulon by the yeast Aft1/Aft2 transcription factors depends on mitochondrial but not cytosolic iron-sulfur protein biogenesis. J Biol Chem. 2005;280(11):10135-40.

56. Wessels D, Srikantha T, Yi S, Kuhl S, Aravind L, Soll DR. The ShwachmanBodian-Diamond syndrome gene encodes an RNA-binding protein that localizes to the pseudopod of Dictyostelium amoebae during chemotaxis. J Cell Sci. 2006;119(Pt 2):370-9.

57. Elghetany MT, Alter BP. p53 protein overexpression in bone marrow biopsies of patients with Shwachman-Diamond syndrome has a prevalence similar to that of patients with refractory anemia. Arch Pathol Lab Med. 2002;126(4):452-5.

58. Rujkijyanont $\mathrm{P}$, Watanabe $\mathrm{K}$, Ambekar $\mathrm{C}$, Wang H, Schimmer A, Beyene $J$, et al. SBDS-deficient cells undergo accelerated apoptosis through the Fas-pathway. Haematologica. 2008;93(3):363-71.

59. Dror $Y$, Freedman MH. Shwachman-Diamond syndrome marrow cells show abnormally increased apoptosis mediated through the Fas pathway. Blood. 2001;97(10):3011-6

60. van Loon AP, Pesold-Hurt B, Schatz G. A yeast mutant lacking mitochondrial manganese-superoxide dismutase is hypersensitive to oxygen. Proc Natl Acad Sci USA. 1986;83(11):3820-4.

61. Irazusta V, Cabiscol E, Reverter-Branchat G, Ros J, Tamarit J. Manganese is the link between frataxin and iron-sulfur deficiency in the yeast model of Friedreich ataxia. J Biol Chem. 2006;281(18):12227-32.

62. Jouihan HA, Cobine PA, Cooksey RC, Hoagland EA, Boudina S, Abel ED, et al. Iron-mediated inhibition of mitochondrial manganese uptake mediates mitochondrial dysfunction in a mouse model of hemochromatosis. Mol Med. 2008;14(3-4):98-108.

63. Herbison CE, Thorstensen K, Chua AC, Graham RM, Leedman P, Olynyk $J \mathrm{~K}$, et al. The role of transferrin receptor 1 and 2 in transferrin-bound iron uptake in human hepatoma cells. Am J Physiol Cell Physiol. 2009;297(6):C1567-75.

64. Rouault TA. Biogenesis of iron-sulfur clusters in mammalian cells: new insights and relevance to human disease. Dis Model Mech. 2012;5(2):155-64

65. Stehling O, Wilbrecht C, Lill R. Mitochondrial iron-sulfur protein biogenesis and human disease. Biochimie. 2014;100:61-77.

66. Schilke B, Voisine C, Beinert $H$, Craig E. Evidence for a conserved system for iron metabolism in the mitochondria of Saccharomyces cerevisiae. Proc Natl Acad Sci USA. 1999;96(18):10206-11.

67. Anderson CP, Shen M, Eisenstein RS, Leibold EA. Mammalian iron metabolism and its control by iron regulatory proteins. Biochim Biophys Acta. 2012;1823(9):1468-83.

68. Outten CE, Albetel AN. Iron sensing and regulation in Saccharomyces cerevisiae: Ironing out the mechanistic details. Curr Opin Microbiol. 2013;16(6):662-8

69. Kumanovics A, Chen OS, Li L, Bagley D, Adkins EM, Lin H, et al. Identification of FRA 1 and FRA2 as genes involved in regulating the yeast iron regulon in response to decreased mitochondrial iron-sulfur cluster synthesis. J Biol Chem. 2008;283(16):10276-86.
70. Wallander ML, Leibold EA, Eisenstein RS. Molecular control of vertebrate iron homeostasis by iron regulatory proteins. Biochim Biophys Acta. 2006;1763(7):668-89.

71. Beyer WF Jr, Fridovich I. In vivo competition between iron and manganese for occupancy of the active site region of the manganese-superoxide dismutase of Escherichia coli. J Biol Chem. 1991;266(1):303-8.

72. Kang Y, He YX, Zhao MX, Li WF. Structures of native and Fe-substituted SOD2 from Saccharomyces cerevisiae. Acta Crystallogr Sect F Struct Biol Cryst Commun. 2011;67(Pt 10):1173-8.

73. Askwith C, Eide D, Van Ho A, Bernard PS, Li L, Davis-Kaplan S, et al. The FET3 gene of $S$. cerevisiae encodes a multicopper oxidase required for ferrous iron uptake. Cell. 1994;76(2):403-10.

74. Chen OS, Hemenway S, Kaplan J. Inhibition of Fe-S cluster biosynthesis decreases mitochondrial iron export: evidence that Yfh $1 p$ affects Fe-S cluster synthesis. Proc Natl Acad Sci USA. 2002;99(19):12321-6.

75. Moreno-Cermeno A, Obis E, Belli G, Cabiscol E, Ros J, Tamarit J. Frataxin depletion in yeast triggers up-regulation of iron transport systems before affecting iron-sulfur enzyme activities. J Biol Chem. 2010;285(53):41653-64.

76. Vaubel RA, Isaya G. Iron-sulfur cluster synthesis, iron homeostasis and oxidative stress in Friedreich ataxia. Mol Cell Neurosci. 2013;55:50-61.

77. Ye H, Rouault TA. Human iron-sulfur cluster assembly, cellular iron homeostasis, and disease. Biochemistry. 2010;49(24):4945-56.

78. Gomez M, Perez-Gallardo RV, Sanchez LA, Diaz-Perez AL, Cortes-Rojo C, Meza Carmen V, et al. Malfunctioning of the iron-sulfur cluster assembly machinery in Saccharomyces cerevisiae produces oxidative stress via an iron-dependent mechanism, causing dysfunction in respiratory complexes. PLoS ONE. 2014;9(10):e111585.

79. Gardner PR, Raineri I, Epstein LB, White CW. Superoxide radical and iron modulate aconitase activity in mammalian cells. J Biol Chem. 1995:270(22):13399-405.

80. Sherman F, Fink GR, Lawrence CW. Methods in yeast genetics. Cold Spring Harbor: Cold Spring Harbor Laboratory Press; 1978.

81. Gietz RD, Schiestl RH. Applications of high efficiency lithium acetate transformation of intact yeast cells using single-stranded nucleic acids as carrier. Yeast. 1991;7(3):253-63.

82. Jensen LT, Culotta VC. Regulation of Saccharomyces cerevisiae FET4 by oxygen and iron. J Mol Biol. 2002;318(2):251-60.

83. Chalermwat C, Thosapornvichai T, Wongkittichote P, Phillips JD, Cox $J$ E, Jensen AN, et al. Overexpression of the peroxin Pex34p suppresses impaired acetate utilization in yeast lacking the mitochondrial aspartate/glutamate carrier Agc1p. FEMS Yeast Res. 2019;19:8.

84. Pongwattanakewin O, Phyu T, Suesattayapirom S, Jensen LT, Jensen AN. Possible role of the $\mathrm{Ca}(2+) / \mathrm{Mn}(2+)$ P-Type ATPase Pmr1p on artemisinin toxicity through an induction of intracellular oxidative stress. Molecules. 2019;24:7.

85. Levine RL, Garland D, Oliver CN, Amici A, Climent I, Lenz AG, et al. Determination of carbonyl content in oxidatively modified proteins. Methods in enzymology. 1990;186:464-78.

86. Luk EE, Culotta VC. Manganese superoxide dismutase in Saccharomyces cerevisiae acquires its metal co-factor through a pathway involving the Nramp metal transporter, Smf2p. J Biol Chem. 2001:276(50):47556-62.

87. Schneider CA, Rasband WS, Eliceiri KW. NIH Image to ImageJ: 25 years of image analysis. Nat Methods. 2012;9(7):671-5.

88. Balcavage WX, Mattoon JR. Properties of Saccharomyces cerevisiae mitochondria prepared by a mechanical method. Biochim Biophys Acta. 1968:153(3):521-30.

89. Giacomini A, Corich V, Ollero FJ, Squartini A, Nuti MP. Experimental conditions may affect reproducibility of the beta-galactosidase assay. FEMS Microbiol Lett. 1992;100(1-3):87-90.

90. Bradford MM. A rapid and sensitive method for the quantitation of microgram quantities of protein utilizing the principle of protein-dye binding. Anal Biochem. 1976;72:248-54.

91. Flohe L, Otting F. Superoxide dismutase assays. In: Packer L, editor. Methods in Enzymology: Oxygen radicals in biological systems. New York: Academic press; 1984. p. 93-104.

92. Ackrell BA, Kearney EB, Singer TP. Mammalian succinate dehydrogenase. Methods Enzymol. 1978;53:466-83.

93. Fansler B, Lowenstein JM. Aconitase from pig heart: EC 4.2.13 Citrate (isocitrate) hydro-lyase. In: Lowenstein JM, editor. Methods in 
Enzymology: Citric Acid Cycle. New York: Academic press; 1969. p. 26-30.

94. Zinser E, Daum G. Isolation and biochemical characterization of organelles from the yeast Saccharomyces cerevisiae. Yeast. 1995;1 (6):493-536.

\section{Publisher's Note}

Springer Nature remains neutral with regard to jurisdictional claims in published maps and institutional affiliations.
Ready to submit your research? Choose BMC and benefit from:

- fast, convenient online submission

- thorough peer review by experienced researchers in your field

- rapid publication on acceptance

- support for research data, including large and complex data types

- gold Open Access which fosters wider collaboration and increased citations

- maximum visibility for your research: over 100M website views per year

At BMC, research is always in progress.

Learn more biomedcentral.com/submissions 